\title{
Laboratorio de
}

empatía: indagando principios éticos para la educación en diseño

UNIVERSIDAD DE LOS ANDES DEPARTAMENTO DE DISEÑO BOGOTÁ, COLOMBIA

mp.baron113@uniandes.edu.co

UNIVERSIDAD DE LOS ANDES DEPARTAMENTO DE DISEÑO BOGOTÁ, COLOMBIA

mm.echavarria357@uniandes.edu.co
María Pauna

Barón

Aristizábal

Margarita

Eqhavarria

Oulinghia
UNIVERSIDAD DE LOS ANDES DESIGN DEPARTMENT

BOGOTÁ, COLOMBIA

mp.baron113@uniandes.edu.co

UNIVERSIDAD DE LOS ANDES DESIGN DEPARTMENT BOGOTÁ, COLOMBIA

mm.echavarria357@uniandes.edu.co \begin{tabular}{l|l|l|l} 
DISEÑA & $17 \quad$ AGOSTO 2020 \\
\hline IS S N
\end{tabular} 0718-8447 2452-4298 (impreso) (electrónico)

COPYRIGHT: CC BY-SA $3.0 \mathrm{CL}$ Artículo de investigación original

Recepción 16 JUN 2020 Aceptación 4 AGO 2020

Cómo citar este artículo: Barón Aristizábal, M. P. \& Echavarría Quinchia, M. (2020). Laboratorio de empatía: indagando principios éticos para la educación en diseño. Diseña, (17), 106-127.

https://doi.org/10.7764/ disena.17.106-127

\begin{tabular}{|c|c|}
\hline DISEÑA 17 & AUGUST 2 \\
\hline \multicolumn{2}{|c|}{ ISSN } \\
\hline $\begin{array}{l}\text { O } 718-8447 \\
\text { (print) }\end{array}$ & $\begin{array}{l}2452-4298 \\
\text { (electronic) }\end{array}$ \\
\hline
\end{tabular}

COPYRIGHT: CC BY-SA $3.0 \mathrm{CL}$ Original

Research Article

Reception JUN $16 \quad 2020$ Acceptance AUG 42020

How to cite this article:

Barón Aristizábal, M. P. \&

Echavarría Quinchia, M. (2020).

Empathy Lab: Ethical Principles Enquiry for Design Education.

Diseña, (17), 106-127.

https://doi.org/10.7764/

disena.17.106-127 
María Paula Barón Aristizábal Diseñadora, Universidad de los Andes. Máster en Textiles, The Glasgow School of Art. Es Profesora Asistente del Departamento de Diseño de la Universidad de Los Andes (Colombia). Su investigación explora la empatía, la ética y la narrativa como fundamentos disciplinares para la construcción de futuros deseables. Es co-autora del libro De uno a todos: Preguntas para construir un proceso de diseño basado en la empatía (con M. Echavarría Quinchia; Uniandes, 2019). Entre sus últimas publicaciones destaca "Can We Help as Designers to Build Relevant Spaces for Meaningful Dialogue through Storytelling as a Tool for Local Empowerment? A Case of Study in the Colombian Pacific" (The Design Journal, vol. 22, sup. 1).

Margarita Echavarría Quinchia Diseñadora Industrial, Universidad de Los Andes. MA en Diseño, University of New South Wales. Es Profesora Asistente en la Facultad de Arquitectura y Diseño de la Universidad de Los Andes (Colombia). Su trabajo de investigación se enfoca en la innovación en materiales, las manufacturas, el bienestar emocional de las personas y la empatía como pieza fundamental del proceso de diseño. Es co-autora del libro De uno a todos: Preguntas para construir un proceso de diseño basado en la empatía (con M. P. Barón Aristizábal; Uniandes, 2019).
María Paula Barón Aristizábal Designer, Universidad de los Andes. MA in Textiles, The Glasgow School of Art. She is an Assistant Professor in the Design Department of the Universidad de Los Andes (Colombia). Her research explores empathy, ethics, and narratives as disciplinary bases for the creation of desirable futures. She is a co-author of Building Trust: Questions to Create an Empathy-based Design Process (with M. Echavarría Quinchia; Uniandes, 2019). Among her latest publications stands out: 'Can We Help as Designers to Build Relevant Spaces for Meaningful Dialogue through Storytelling as a Tool for Local Empowerment? A Case of Study in the Colombian Pacific' (The Design Journal, Vol. 22, Sup. 1).

Margarita Echavarría Quinchia Industrial Designer, Universidad de Los Andes. MA in Design, University of New South Wales. She is an Assistant Professor at the Faculty of Architecture and Design of the Universidad de Los Andes (Colombia). As a researcher, she focuses on materials innovation, manufacturing, people's emotional well-being, and empathy as a fundamental part of the design process. She is a co-author of: Building Trust: Questions to Create an Empathy-based Design Process (with M. P. Barón Aristizábal; Uniandes, 2019). 
RESUMEN En este artículo describimos el proceso de creación de un set de herramientas destinado a desencadenar en los estudiantes una reflexión sobre los aspectos éticos del proceso de diseño, de modo que puedan desarrollar una ética individual. Siguiendo a Wildevuur, Van Dijk y Schot, entendemos el proceso de diseño como una práctica que exige una actitud de consciencia y apertura, mediada por intercambios que combinan expectativas y vínculos emocionales que apoyan la identidad, la independencia y el reconocimiento mutuo. En consecuencia, el set de herramientas propone enfrentar diferentes retos académicos

Palabras clave:
Ética
Investigación cualitativa
Pensamiento de diseño
Ciudadanía
Educación
cuyo objetivo común es incluir la empatía en las diferentes etapas del proyecto de diseño. A partir de la iteración del set, proponemos tres nuevos principios para la inclusión de la ética en el proceso de diseño: admiración, compromiso e integridad. Estos principios expanden los tres conceptos planteados por IDEO, respeto, each.

responsabilidad y honestidad, abordando una dimensión más emocional de cada uno.
ABSTRACT In this article, we describe the process of creating a toolkit intended to trigger a reflection on the ethical aspects of the design process in students, so that they can develop individual ethics. Following Wildevuur, Van Dijk and Schot, we understand the design process as a practice that requires awareness and openness, through exchanges that combine expectations and emotional ties that support identity, independence, and mutual recognition. Consequently, the toolkit proposes to face different academic challenges whose common aim is to include empathy in the different stages of a design project. Building from the
Keywords:

Ethics

Qualitative research

Design thinking

Citizenship

Education iteration of the toolkit, we propose three new principles for the inclusion of ethics in the de-

sign process: admiration, commitment, and integrity. These principles expand the three concepts raised by IDEO - respect, responsibility, and honesty, addressing a more emotional dimension of 


\section{DISEÑANDO EN UN MUNDO COMPLEJO}

Diseña todo aquel que idea medidas de acción dirigidas a cambiar situaciones existentes por situaciones preferibles (Simon, 2019, p. 111), por tanto, el diseño podría entenderse como una intervención intencional en una situación. Victor Papanek (2012) se refirió a los diseñadores como guardianes, recordando el poder, la agencia y la responsabilidad de la práctica. Papanek también afirma que la práctica sin reflexión no es diseño y sostiene que, aunque su naturaleza inquisitiva la hace tremendamente valiosa, lo único que importa de esta práctica es cómo se relaciona con las personas (2012). Estas últimas no miran las interfaces para apreciarlas, las usan en sus vidas, lo que hace al diseñador responsable de lo que pone en el mundo (Monteiro, 2019, p. 19). Al elegir ser diseñadores elegimos impactar a las personas que entran en contacto con nuestro trabajo, y dicho impacto debe implicar siempre una reflexión acerca del proceso de diseño (Monteiro, 2019, p. 19).

Desde la Revolución Industrial, la sociedad occidental se ha beneficiado de la ciencia, la lógica y el reduccionismo, por sobre la intuición y el holismo. Psicológica y políticamente preferiríamos suponer que la causa de un problema está "allá afuera”, en lugar de "aquí". Es casi irresistible culpar a algo o a otra persona, alejar la responsabilidad de nosotros mismos y buscar la perilla de control, el producto, la píldora, la solución técnica que hará que un problema desaparezca (Meadows, 2008, p. 4).

Como señala Meadows (2008), cuando encontramos la relación entre estructura y comportamiento comprendemos cómo funcionan los sistemas y las relaciones, de tal forma que podemos intervenirlos para mejorar patrones de comportamiento. Un sistema es un conjunto de elementos (humanos y no humanos) interconectados, y dichas conexiones pueden ser influenciadas por fuerzas externas (Meadows, 2008). Cuando dichas fuerzas son acciones de diseño, se hace necesario considerar aspectos éticos y, por tanto, incluir la ética en la educación de los diseñadores se torna imprescindible.

\section{TO DESIGN IN A COMPLEX WORLD}

Anyone conceiving action measures aimed at changing existing situations for preferable situations is a designer (Simon, 2019, p. 111); therefore, design could be understood as an intentional intervention in a situation. Victor Papanek (2012) referred to designers as guardians, recalling the power, agency, and responsibility of practice. Papanek also affirms that practice without reflection is not design and argues that although its inquisitive nature makes it tremendously valuable; the only thing that matters about this practice is how it relates to people (2012). Individuals do not look at the interfaces to appreciate them, they use them in their lives, which makes the designer responsible for what is added to the world (Monteiro, 2019, p. 19). By choosing to be designers, we choose to impact the people who encounter our work and this impact must always imply a reflection on the design process (Monteiro, 2019, p. 19).

Ever since the Industrial Revolution, Western society has benefited from science, logic, and reductionism over intuition and holism. Psychologically and politically we would much rather assume that the cause of a problem is "out there," rather than "in here." It's almost irresistible to blame something or someone else, to shift responsibility away from ourselves, and to look for the control knob, the product, the pill, the technical fix that will make a problem go away. (Meadows, 2008, p. 4)

As Meadows (2008) points out, when we discover the relation between structure and behavior, we understand how systems and relations work, in such a way that we can intervene them to improve behavioral patterns. A system is a set of interconnected elements (human and non-human) and these connections can be influenced by external forces (Meadows, 2008). When these forces are design actions, it is necessary to consider ethical aspects; therefore, including ethics in the education of designers becomes essential. 
En este panorama, el diseñador tiene un desafío: sus reflexiones sobre las relaciones humanas se convierten en eje central de la práctica. Diseñar para la conexión humana se refiere a diseñar para las relaciones que unas personas construyen con otras, considerando también su impacto en lo no-humano. Generalmente, las personas que se sienten socialmente conectadas contribuyen a su comunidady, de esa forma, construyen el llamado capital social (Wildevuur et al., 2014). El diseño parte de entender profundamente a las personas, de comprender la particularidad de sus acciones y el impacto de estas en los sistemas complejos. Esto hace que el diseño se convierta en una disciplina que combina su naturaleza experimental y de acción con el contacto directo con las personas. Un escenario provocador para el diseñador del presente.

\section{LA ÉTICA Y LA EMPATÍA EN LOS PROCESOS DE DISEÑO}

El diseñador debe tener como eje fundamental de su práctica la reflexión sobre las consecuencias que tienen sus acciones sobre los sistemas y en las relaciones humanas para las que diseña. En el contexto de las múltiples crisis actuales, reflexionar sobre la práctica de la disciplina es más importante que nunca. Para Nussbaum (2005), cultivar la "humanidad" en el mundo actual requiere tres habilidades. La primera es la capacidad de realizar un examen crítico de uno mismo que permita experimentar lo que, siguiendo a Sócrates, se puede denominar una vida examinada, donde todo se cuestiona y solo se acepta aquello que supera un razonamiento lógico y una reflexión profunda, convirtiendo a los individuos en ciudadanos capaces de pensar por sí mismos en lugar de remitirse solamente a los juicios de otros (Nussbaum, 2005). La segunda habilidad es la capacidad de las personas de verse a sí mismas como individuos pertenecientes a un grupo más grande, conectados a los demás seres humanos por lazos de reconocimiento y mutua preocupación, entendiendo que las necesidades y objetivos comunes pueden darse en forma distinta según las circunstancias (Nussbaum, 2005). Y la tercera habilidad, que Nussbaum llama "imaginación narrativa", es la capacidad de pensar
In this context, designers have a challenge: their reflections on human relations become the central axis of the practice. Designing for human connection refers to designing for the relations that some people build with others, also considering their impact on the non-human. Cenerally, people who feel socially connected contribute to their community and in this way, build the socalled social capital (Wildevuur et al., 2014). Design starts from deeply understanding people, from understanding the particulars of their actions and their impact on complex systems. This makes design a discipline that combines its experimental and action-driven nature with direct contact with people. A provocative scenario for the designer of the present.

\section{ETHICS AND EMPATHY IN THE DESIGN \\ PROCESSES}

As a fundamental axis of their practice, designers must reflect on the consequences that their actions have on the systems and on the human relations for which they design. In the context of our current multiple crises, reflecting on disciplinary practice is more important than ever. For Nussbaum (2005), cultivating 'humanity' in today's world requires three skills. The first one is the ability to carry out a critical examination of oneself, which enables to experience what, according to Socrates, can be called an examined life, where everything is questioned and only what overcomes logical reasoning and deep reflection is accepted, transforming individuals into citizens capable of thinking for themselves, instead of only referring to the judgment of others (Nussbaum, 2005). The second one is the ability of people to see themselves as individuals belonging to a larger group, connected to other human beings by ties of recognition and mutual concern, understanding that common needs and objectives can occur differently, depending on circumstances (Nussbaum, 2005). The third skill, which Nussbaum calls "narrative imagination", is the ability to think what it 
cómo sería estar en el lugar de otra persona, comprendiendo sus emociones y anhelos, con un sentido crítico en el que ponemos nuestros propios juicios en el encuentro con el otro (2005).

Entender el mundo desde el punto de vista del otro es esencial para cualquier juicio responsable, puesto que no sabremos lo que estamos juzgando hasta no ver el significado de una acción según la intención de la persona que la realiza, ni entenderemos el significado de un discurso mientras no conozcamos la importancia de lo que expresa en el contexto de la historia y el mundo social de esa persona. La tercera capacidad que nuestros estudiantes deben alcanzar es la de descifrar dichos significados mediante su imaginación (Nussbaum, 2005, p. 30).

Como educadoras de futuros diseñadores encontramos un panorama complejo, en el que los estudiantes, con nuestra guía, deben reconocer su conexión individual con el colectivo, evaluar sus acciones dentro del proceso de diseño y ser sensibles a las diversas realidades humanas. Es importante resaltar que el diseño no tiene un código ético universal establecido, y que no se rinde un examen ni se tramita un permiso para el ejercicio profesional. Por ende, no hay licencia para ejercer sanción cuando se cruzan los límites. Esto no significa que la ética no sea una preocupación dentro del pensar y hacer de la disciplina. Comprender el poder en nuestro trabajo y cómo elegimos usarlo define el tipo de personas que somos.

Un diseñador utiliza su experiencia al servicio de otros sin ser un sirviente. Decir "no" es una habilidad de diseño. Preguntar por qué es una habilidad de diseño. Poner los ojos en blanco y permanecer en silencio no lo es. Preguntarnos a nosotros mismos por qué estamos haciendo algo es una pregunta infinitamente mejor que preguntarnos si podemos hacerlo (Monteiro, 2019, p. 21).

Para definir la responsabilidad profesional es necesario discutir el propósito del diseño. Findeli sostiene que no puede haber un diseño responsable sin un diseñador responsable, es decir, la educación debe would be like to be in the place of another person, understanding their emotions and desires with a critical sense in which we put our own judgment in the encounter with the other (2005).

Understanding the world from the point of view of the other is essential to any responsible act of judgment since we do not know what we are judging, until we see the meaning of an action as the person intends it, the meaning of a speech as it expresses something of importance in the context of that person's history and social world. The third ability our students should attain is the ability to decipher such meanings through the use of the imagination.

(Nussbaum, 2005, p. 30)

As educators of future designers, we find a complex panorama in which students must recognize their individual connection to the collective, evaluate their actions within the design process and be sensitive to various human realities, under our guidance. It is important to note that design does not have an established universal code of ethics, an evaluation process, nor is there a permit requested for professional practice. Therefore, there is no license to exercise sanction when the limits are exceeded. This does not mean that ethics is not a concern within the disciplinary thinking and doing. Understanding the power in our work and how we choose to use it, defines the kind of people we are.

A designer uses their expertise in the service of others without being a servant. Saying no is a design skill. Asking why is a design skill. Rolling your eyes and staying quiet is not. Asking ourselves why we are making something is an infinitely better question than asking ourselves whether we can make it. (Monteiro, 2019, p. 21)

To define professional responsibility, it is necessary to discuss the purpose of design. Findeli argues that there can be no responsible design without a responsible designer, therefore, educa- 
estar dirigida al desarrollo de una ética individual (2001, p. 13). Asimismo, el "diseño positivo", una filosofía de innovación centrada en el bienestar humano, enmarca en tres pilares el trabajo para lograr el bienestar: diseño en relación con el placer, con el significado personal y, por último, con el comportamiento virtuoso (Desmet \& Pohlmeyer, 2013). Este último pilar propone reflexionar sobre la idea de tener un comportamiento honorable y sobre la manera en que el razonamiento moral sobre el actuar puede llevar a tomar mejores decisiones frente a los productos que diseñamos (Desmet \& Pohlmeyer, 2013). De ahí la pertinencia de integrar la perspectiva ética en la formación de futuros diseñadores.

En este entramado hay dos palabras clave para los diseñadores: no y por qué. Estas palabras son la base de nuestro marco ético. Si no podemos preguntar "por qué", perdemos la capacidad de reflexionar sobre el impacto de lo que estamos haciendo. Lo que elegimos diseñar, lo que elegimos no diseñar y a quién excluimos del proceso de diseño son actos políticos (Monteiro, 2019, p. 19). Diseñar incidiendo en las relaciones sociales, valorando las experiencias de otros y construyendo un entendimiento compartido se convierte en el cimiento del capital social. En una mirada más humanista al tradicional proceso de diseño, el diseñador entiende las relaciones sociales como un regulador del bienestar de las personas, donde el contacto social y las sanas relaciones tienen un efecto directo en la salud mental y física de las personas. Un proceso de diseño que parte de una actitud de consciencia y apertura, mediado por intercambios que combinan expectativas, tiene como resultado la creación de vínculos emocionales que apoyan la identidad, la independencia y el reconocimiento (Wildevuur et al., 2014).

Un proceso de diseño exitoso está basado en la colaboración y la confianza que se establece entre las personas y el equipo de diseño, pues la información que recolectamos y las intervenciones que hacemos con las personas dependen de esto. Poner en práctica principios éticos favorece dicha colaboración. Para Kelley, Suri e IDEO (2016), una colaboración basada en la empatía y la sensibilidad cultural debe incluir tres tion must be directed towards the development of individual ethics (2001, p. 13). Likewise, positive design, a philosophy of innovation focused on human well-being, frames in three pillars the work in order to achieve well-being: design in relation to pleasure, with personal significance and finally, with virtuous behavior (Desmet \& Pohlmeyer, 2013). This last pillar proposes to reflect about having an honorable behavior and on the way in which moral reasoning when acting can lead to better decisions regarding the products we design (Desmet \& Pohlmeyer, 2013). Hence the relevance of integrating an ethical perspective in the training for future designers.

Considering the aforementioned, there are two keywords for designers: no and why. These words are the foundation of our ethical framework. If we cannot ask 'why', we lose the ability to reflect on the impact of what we do. What we choose to design, what we choose not to design, and whom we exclude from the design process, are political acts (Monteiro, 2019, p. 19). To design influencing social relationships, valuing the experiences of others and building a shared understanding, becomes the foundation of social capital. With a more humanistic view of the traditional design process, the designer understands social relations as regulators of people's well-being, where social contact and healthy relations have a direct effect on people's mental and physical health. A design process that starts from an attitude of awareness and openness, mediated by exchanges that combine expectations, exacts the creation of emotional bonds that support identity, independence, and recognition (Wildevuur et al., 2014).

A successful design process is based on the collaboration and trust established between people and the design team since the information we collect and the interventions we make with people depend on this. Putting ethical principles into practice favors such collaboration. Following Kelley, Suri, and IDEO (2016), a collaboration based on empathy and cultural sensitivity must include 
grandes conceptos: respeto, responsabilidad y honestidad. Cada uno de estos aspectos plantea cuestionamientos para un estudiante de diseño. El respeto nos invita a preguntarnos cómo tratamos a los sujetos, si estamos considerando sus sensibilidades culturales y cuál es el impacto de nuestras acciones (Kelley et al., 2016). Considerar la responsabilidad en el proceso de diseño implica una actitud que va desde pensar los posibles efectos de las actividades de investigación hasta las consecuencias de compartir información y el futuro tratamiento que se debe dar a esta (Kelley et al., 2016). Finalmente, la honestidad nos invita a ser claros con los procesos y veraces con los alcances del proyecto (Kelley et al., 2016).

El gran aporte de Kelley, Suri e IDEO está en conectar los principios éticos que proponen (respeto, responsabilidad y honestidad) con las etapas del proceso de diseño. Dichos autores señalan que, en la etapa de descubrimiento, que consiste en observar una situación, las personas y sus contextos, surgen inquietudes sobre cómo construir un lenguaje común, conseguir permisos, trabajar en explicaciones claras o mantener al equipo alineado con el contexto (2016). Tanto en esta etapa como en una posterior, la de prototipar, consistente en hacer comprobaciones y entender las limitaciones de las primeras ideas, es importante construir una relación de colaboración con la comunidad, para lo cual se deben manejar las expectativas, el tiempo disponible y las necesidades de las personas (Kelley et al., 2016). Kelley, Suri e IDEO proponen que, al pasar a la etapa de interpretar, donde se analiza la información y los hallazgos o revelaciones que ayudan a entender a las personas y a identificar situaciones de valor dentro de una comunidad, debe considerarse el motivo por el cual las personas comparten información y hay que proteger a los participantes manteniendo seguro el material de registro (2016). Al idear, cuando se generan propuestas y se encuentran oportunidades o soluciones a partir de los hallazgos, es importante no prometer lo que no se puede cumplir y utilizar solamente la información necesaria, de modo que se proteja la intimidad de los participantes, así como considerar sus sensibilidades personales y culturales (Kelley et al., 2016). three main concepts: respect, responsibility, and honesty. Each of these aspects raises questions to a design student. Respect invites us to ask ourselves how we treat people, if we are considering their cultural sensitivities and what is the impact of our actions (Kelley et al., 2016). Considering responsibility in the design process, implies an attitude that ranges from thinking about the possible effects of research activities, to the consequences of sharing information and the future approach that should be given to it (Kelley et al., 2016). Finally, honesty invites us to be clear with the processes and truthful with the scope of the project (Kelley et al., 2016).

The great contribution made by Kelley, Suri, and IDEO is that they connect the ethical principles they propose (respect, responsibility, and honesty) to the stages of the design process. These authors point out that in the discovery stage, which consists of observing a situation, people and their contexts, concerns arise on how to build a common language, get permissions, work on clear explanations, or keep the team aligned to the context (2016). In this stage and in a later one, that of prototyping, consisting of testing and understanding the limitations of the initial ideas, to build a collaborative relation to the community is important, for which the expectations, the available time and the needs of people must be managed (Kelley et al., 2016). Kelley, Suri, and IDEO propose that when moving to the interpretation stage, where information and findings or insights that help to understand people and identify situations of value within a community, are analyzed. The reason why people share information must be considered, and participants must be protected by keeping records secure (2016). During ideation, when proposals are generated and opportunities or solutions are derived from the findings, it is important not to promise what cannot be fulfilled; to use only the necessary information - so that participant's privacy is protected - and to consider people's personal and cultural sensitivities (Kelley et al., 2016). 
Los diseñadores tenemos la obligación de conducir investigaciones y proyectos beneficiosos que favorezcan la construcción de redes sociales, sin dejar de lado la capacidad de explorar e improvisar. Como señala Coe Leta Stafford,

A primera vista, parecería que la ética y la creatividad no tienen nada en común; una está constreñida y la otra desenfrenada. $Y$, sin embargo, la ética da la mano a un mundo de placeres inesperados y puntos de partida para la creatividad. El secreto para conseguir que otras personas compartan sus secretos es conducirse con el mayor respeto (como se citó en Kelley et al., 2016, p. 53).

Basándonos en todo lo anterior, hemos propuesto tres nuevos principios para la inclusión de la ética dentro del proceso de diseño: admiración, compromiso e integridad. Estos principios parten de los tres conceptos planteados por Kelley, Suri e IDEO (2016): respeto, responsabilidad y honestidad, a los que hemos añadido una extensión o evolución que aborda una dimensión más emocional de cada concepto. El respeto se convierte en admiración. Así, mientras el primero asegura la autonomía, el segundo la cuida; mientras el respeto se limita a valorar las opiniones y las elecciones, el segundo convierte la valoración en aprecio; mientras el respeto considera el contexto y conoce los límites, su evolución, la admiración, disfruta del contexto. La responsabilidad, por su parte, se transforma en compromiso. Mientras la primera busca proteger a las personas, el compromiso busca animarlas, así como a sus intereses. Mientras la responsabilidad invita a no hacer daño, el segundo busca, además, reducir los riesgos. Así, la responsabilidad evoluciona hacia un compromiso con los usuarios y el proyecto. Finalmente, la honestidad es ahora integridad. Mientras la honestidad garantiza la veracidad de la información y evade expectativas falsas, la integridad promueve ser justo con la comunicación y las acciones, valorando tanto la verdad como la coherencia y alentando en los usuarios el bienestar.
Designers have the obligation to conduct research and beneficial projects that favor the creation of social networks, without neglecting the ability to explore and improvise. As Coe Leta Stafford points out:
At first glance, it appears that ethics and creativity have nothing in common; one is constrained and the other unbridled. And yet, ethics is the insider handshake to a world of un- expected delights and creative starting points. The secret to getting others to share their secrets is to conduct yourself with the utmost respect. (As cited in Kelley et al., 2016, p. 53).

Based on what we have outlined, we propose three new principles for the inclusion of ethics in the design process: admiration, commitment, and integrity. These principles are based on the three concepts proposed by Kelley, Suri and IDEO (2016) - respect, responsibility and honesty, to which we have added an extension or evolution that addresses a more emotional dimension to each of them. Respect turns into admiration. Thus, while the first ensures autonomy, the second takes care of it; while respect is limited to valuing opinions and choices, the second turns valuation into appreciation; while respect considers the context and knows the limits, its evolution, admiration, enjoy the context. Responsibility, for its part, becomes commitment. While the former seeks to protect people, commitment seeks to encourage them together with their interests. While responsibility invites us to do no harm, the second also seeks to reduce risks. Thus, responsibility evolves towards a commitment to the users and the project. Finally, honesty is now integrity. While honesty guarantees the veracity of information and avoids false expectations, integrity promotes being fair with communication and actions, valuing both truth and consistency and encouraging the well-being of users. 
Indagando el proceso de diseño en el aula: creación del set de herramientas

Entre las herramientas de diseño para indagar la empatía se encuentran el People Value Canvas (PVC) y el Design for Empathy Toolkit. El PVC ayuda a estructurar las necesidades y preferencias de los usuarios y a describir la propuesta de valor utilizando la empatía como un medio para el impacto social (Wildevuur et al., 2014). A su vez, el Design for Empathy Toolkit busca un proceso de diseño más empático a través de estrategias como enganchar, contar historias y experimentar la solidaridad (Burton et al., 2013). Sin embargo, estas dos herramientas no abordan la reflexión desde el proceso de diseño, sino como el objetivo de diseño, por lo que consideramos pertinente aportar a la indagación en los asuntos éticos implicados en el proceso.

A continuación, describimos en primera instancia la experiencia realizada en el curso de pregrado EmpathyLab, en el que estudiantes de tercer a octavo semestre de diseño se enfrentaban a diferentes retos académicos que tenían como objetivo explorar la inclusión de la empatía en las diferentes etapas de un proyecto de diseño. Luego de discutir los principios éticos propuestos con los estudiantes, los invitamos a crear actividades que nutrieran, desde la ética y la empatía, cada etapa del proceso de diseño. Para esto, propusimos cuatro etapas en las cuales estimulábamos reflexiones específicas: (1) Planear y observar: los estudiantes fueron invitados a pensar acerca del tratamiento de la información y sobre la importancia de entender el contexto, presentarse ante la comunidad como equipo de trabajo y dar a los participantes la posibilidad de hacerse parte del proceso en forma voluntaria. (2) Idear y prototipar: los estudiantes fueron incitados a reconocer la importancia de la empatía en esta etapa, haciendo reflexiones sobre lo cómodo o embarazoso que pueden llegar a ser para las personas las actividades de validación de un producto o servicio que se está diseñando. (3) Recoger y compartir: los estudiantes fueron motivados a reflexionar sobre el manejo de las expectativas frente al proyecto y sus resultados. En esta fase discutimos sobre la importancia de considerar los sentimientos de los participantes

\section{Inquiring the design process in the classroom: Creating the toolkit}

Among the design tools to explore empathy, we find People Value Canvas (PVC) and the Design for Empathy Toolkit. PVc helps to structure the needs and preferences of users and to describe the value proposition using empathy as a means for social impact (Wildevuur et al., 2014). In turn, the Design for Empathy Toolkit seeks a more empathic design process through strategies such as engaging, telling stories, and experiencing solidarity (Burton et al., 2013). However, these tools do not address reflection from the design process, but rather as the design objective, therefore we consider it pertinent to contribute to the inquiry into the ethical issues involved in the process.

Next, we first describe the experience carried out in the EmpathyLab undergraduate course, in which Design students from the third to eighth semester encountered different academic challenges aimed to explore the inclusion of empathy in the different stages of a design project. After discussing the proposed ethical principles with the students, we invited them to create activities that nurtured, from ethics and empathy, each stage of the design process. For this, we proposed four stages in which we stimulated specific reflections: (1) Plan and Observe: the students were invited to think about the treatment of the information and the importance of understanding the context, presenting themselves to the community as a work team and giving participants the possibility of becoming part of the process voluntarily. (2) Devise and Prototype: students were encouraged to recognize the importance of empathy at this stage, reflecting on how comfortable or embarrassing the validation activities of a product or service being designed could mean for people. (3) Collect and Share: the students were motivated to reflect on the management of expectations regarding the project and its results. In this phase, we discuss the importance of considering the feelings of the participants when sharing the information that is 
al compartir la información que se recopila. (4) Finales felices: los estudiantes son llamados a pensar sobre la importancia de mostrar el trabajo y el resultado, tanto a los colaboradores como al mundo, a considerar el impacto del proyecto y a dar un cierre al proceso creando un final feliz a la colaboración con los usuarios.

En el ejercicio realizado en la primera versión del curso, comenzamos con la discusión de los conceptos y su relación con las etapas de diseño. Invitamos a los equipos de estudiantes a proponer actividades que los ayudaran a resolver los dilemas morales que identificaron en esos momentos clave de su trabajo con personas. Centramos las actividades alrededor de cuatro categorías: los tres principios éticos que establecimos anteriormente, admiración, compromiso e integridad, más el lenguaje, pues los estudiantes encontraban un obstáculo importante en su trabajo de campo. Los estudiantes propusieron actividades prácticas que registraban en tarjetas de fácil uso, en las cuales debían definir una de las categorías y una de las etapas del proceso de diseño mencionadas anteriormente, así como un objetivo específico, e indicar si la actividad estaría dirigida al equipo de diseño, a los usuarios o a ambos. En las tarjetas proponían actividades que facilitaran la aplicación de los conceptos éticos a las diferentes etapas del proceso de diseño. Por ejemplo, abordaron la admiración transformando a los participantes en superhéroes y buscando sus súper poderes; trabajaron con el compromiso a través de premios simbólicos, donde cada tarea realizada por el equipo fue valorada públicamente; $y$ abordaron el lenguaje creando una actividad llamada "diario corporal", donde registraron gestos, movimientos y emociones.

Notamos que la libertad que dimos para la creación de las tarjetas dio como resultado que muchas de estas no especificaran las instrucciones necesarias para la actividad. Al socializar las propuestas de tarjetas en el aula, los estudiantes plantearon nuevas dudas y reflexiones en cuanto al impacto de su interacción con las personas y la dificultad que encontraban para registrar esos encuentros. Para responder a esto, construimos dos nuevas categorías. La primera es futuro. $\mathrm{Su}$ valor radica en que promueve que los estudiantes collected. (4) Happy Endings: students are called to think about the importance of showing the work and the results, both to the collaborators and to the world, to consider the impact of the project, and to close the process by creating a happy ending to the collaboration with the users.

In the exercise carried out in the first version of the course, we began with the discussion of the concepts and their relation to each design stage. We invited the student teams to propose activities that would help them solve the moral dilemmas that they identified in those key moments of their interaction with people. We centered the activities around four categories: the three ethical principles that we established earlier-admiration, commitment, and integrity, plus language, since the students encountered a significant obstacle in their field work. The students proposed practical activities that they registered on easy-to-use cards, in which they had to define one of the categories and one of the stages of the design process mentioned above, as well as a specific objective and to indicate whether the activity would be addressed to the design team, users, or both. They proposed on the cards, activities that would facilitate the application of ethical concepts to the different stages of the design process. For example, they addressed admiration by transforming the participants into superheroes and seeking their super powers; they worked with commitment through symbolic awards, where each task performed by the team was publicly valued; and they approached language by creating an activity called 'corporal diary', where they registered gestures, movements, and emotions.

We noticed that the freedom we gave to create the cards resulted in many of the cards not specifying the necessary instructions given for the activity. By sharing the card proposals throughout the classroom, the students raised new doubts and reflections regarding the impact of their interaction with people and the difficulty they encountered when registering them. To solve this, 
reflexionen y se planteen preguntas como ¿qué pasará con el producto o servicio diseñado?, ¿cuánto tiempo permanecerá en el mundo?, ¿qué usos inesperados puede detonar? La segunda categoría que agregamos fue nuevos medios, que considera la relevancia de la comunicación, la información y la tecnología en la actualidad.

En la segunda iteración del ejercicio desarrollamos los principios éticos y entregamos a los estudiantes un conjunto de fichas prediseñadas para facilitar el diseño de las actividades que debían proponer (Figura 1). Esto, junto con la guía y la retroalimentación que entregamos como profesoras, resultó en actividades y reflexiones más complejas. La Figura 1 muestra las fichas diseñadas para guiar los talleres y las discusiones dentro del aula. Además de incluir los atributos prácticos que resultaron acertados en la primera versión (el tiempo, la etapa del proceso de diseño para la cual es la actividad, para quién es y a qué principio responde), estas fichas proponen una especificidad mayor en términos de objetivos, intenciones, etapas y actividades.

La mayoría de las actividades planteadas por los estudiantes incluían dinámicas autocríticas y de autoevaluación. La reflexión trascendió a las comunidades y llegó hasta el propio equipo de diseño. Por ejemplo, aparecieron actividades como "A prueba de mentiras blancas", que buscaba evitar aquellas ocasiones en que el equipo de diseño puede manipular información sin darse cuenta; o "Cabeza en la luna, pies en la tierra", destinada a aterrizar la información en acciones prácticas. Otras actividades buscaban fomentar el compromiso del equipo de diseño, una de las cuales fue "Boda grupal", un ritual simbólico a través del cual todos reflexionan sobre su nivel de compromiso con el proyecto y sus actividades.

A partir de esta experiencia, concluimos que las herramientas deben tener una guía que introduzca los principios, con ejemplos concretos y prácticos. Junto con ello, el uso de estas detona nuevas dudas o reflexiones, por lo que el set de herramientas debe dar espacio para que los estudiantes creen sus propias actividades. Finamente, debido a las inquietudes y la curiosidad we created two new categories. The first one is future. Its value lies in the fact that it encourages students to reflect and ask themselves questions such as, what will happen to the designed product or service? How long will it remain in the world? What unexpected uses can it trigger? The second category we added was new media, which considers the relevance of our current communication, information, and technology.

In the second iteration of the exercise, we developed the ethical principles and gave the students a set of pre-designed forms to facilitate the design of the activities they had to propose (Figure 1). This, along with the guidance and feedback we provided as teachers, resulted in more complex activities and reflections. Figure 1 shows the forms designed to guide workshops and discussions within the classroom. In addition to including the practical attributes that were successful in the first version (the time, the stage of the design process in which the activity is, for whom it is and what principle it responds to), these cards propose a greater specificity in terms of objectives, intentions, stages, and activities.

Most of the activities proposed by the students included self-critical and self-assessment dynamics. The reflection transcended the communities and reached the design team itself. For example, activities such as 'White-lies proof' appeared, which sought to avoid those occasions when the design team can unknowingly manipulate information; or 'Head on the Moon, Feet on the Ground', intended to ground the information into practical actions. Other activities sought to encourage the commitment of the design team, one of which was 'Group Wedding', a symbolic ritual through which everyone reflects on their level of commitment to the project and its activities.

From this experience we conclude that the tools should have a guide that introduces the principles, with concrete and practical examples. Together with it, the use of these generates new doubts or reflections, therefore the set must pro- 
CATEGoría

Definir usuarios

Definir intenciones

Construir hallazgos

Ideación y concepto

Prueba

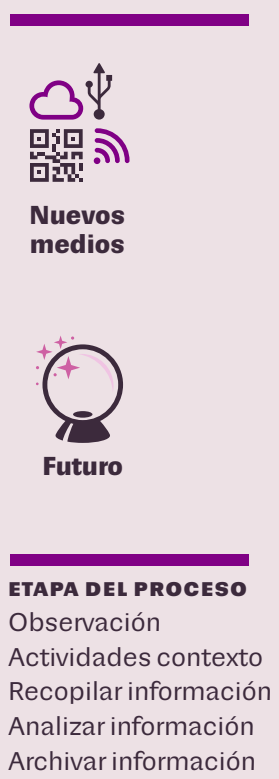

¿PARA QUIÉNES?

Equipo de diseño

Usuarios + equipo

de diseño

Usuarios

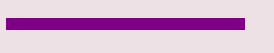

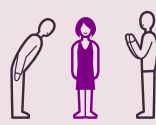

Admiración

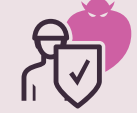

Integridad

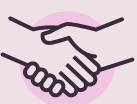

Compromiso

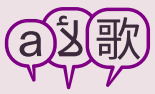

Lenguaje
¿CUÁNTO TIEMPO

PUEDE TOMAR?
¿Cómo se integran en acciones prácticas en el proceso de diseño?

¿Qué es?

\section{DEFina intenciones}

¿Qué intentan resolver con

esta tarjeta / actividad?

Objetivos

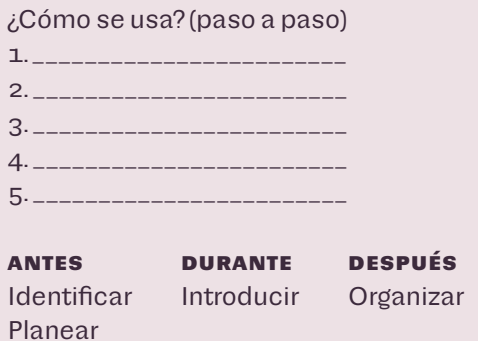

Planear

DEFINA EXPECTATIVAS

¿Qué intentan obtener con esta tarjeta/actividad?

Resultados
A.
B.
Figura 1: Ficha en la que, además de incluir los conceptos usados en la versión anterior, se incluyeron las intenciones, las expectativas y la duración de tiempo de la actividad. Fuente: Las autoras, rediseñada. que genera el set, este debe contener referencias para quienes quieran ahondar en sus reflexiones (en este caso, libros de consulta como The Little Book of Design Research Ethics y Designing for Empathy: A Toolkit Created by Artefact resultaron fundamentales). Estas conclusiones nos permitieron generar un nuevo set que socializamos con los estudiantes.

\section{Evaluación de la propuesta: set de tarjetas para reflexionar}

Entendemos la evaluación de una propuesta pedagógica como la recolección sistemática de información en función de las características, actividades y resultados de una implementación (Bamberger, 2012). El análisis de los resultados permite a los interesados expandir la comprensión acerca del diseño y la implementación de vide space for students to create their own activities. Finally, due to the concerns and curiosity generated by the toolkit, it should contain references for those who want to deepen their reflections (in this case, references such as The Little Book of Design Research Ethics and Designing for Empathy: A Toolkit Created by Artefact were fundamental). These conclusions allowed us to generate a new set that we shared with the students.

\section{Proposal evaluation: Set of reflection cards}

We understand the evaluation of a pedagogical proposal as the systematic collection of information based on the characteristics, activities, and results of an implementation (Bamberger, 2012). The analysis of the results, enables stakeholders 


\section{CATEGORY}

Define users

Define intentions

Build findings

Ideation and concept

Test

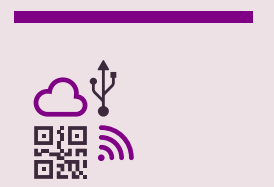

New media

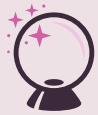

Future

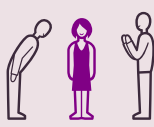

Admiration

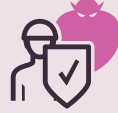

Integrity

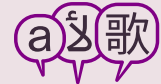

Language

\section{Design team}

Users + design

team

Users

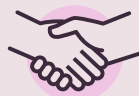

Commitment

HOW LONG

CAN IT TAKE?
PROCESS STAGE

Observation

Activities context

Gather information

Analyze information

Archive information
How are they integrated into practical actions in the design process?

What is it?

\section{DEFINE INTENTIONS}

What are you trying to solve

with this card/activity?

Objectives

How to use? (step by step)

1.

3.

4.

5 .

\section{BEFORE DURING AFTER \\ Identify Introduce Organize}

To plan

\section{DEFINE EXPECTATIONS}

What are you trying to get with this card/activity?

Results
A.

la propuesta aquí descrita, con el fin de tomar decisiones informadas para mejorar los programas educativos (Greene et al., 2011), en este caso, cómo se abordan los aspectos éticos en los programas educativos de diseño. Teniendo en cuenta el objetivo de esta investigación, nuestro interés estuvo focalizado en analizar cómo cambiaban las percepciones de los estudiantes a la hora de abordar problemas de carácter ético en proyectos de diseño. Para ello, optamos por una aproximación de carácter cualitativo: un cuestionario de pregunta abierta destinado a recoger percepciones, el cual fue implementado a manera de pre-test (al principio de la experiencia) y post-test (al final de la experiencia) (Oliver-Hoyo \& Allen, 2006). Nos inclinamos por un cuestionario de pregunta abierta porque ofrece la posibilidad de recoger explicaciones de los procesos internos to expand their understanding of the design and implementation of the proposal here described in order to make informed decisions to improve educational programs (Greene et al., 2011), in this case particularly, how ethical aspects are addressed in educational design programs. Considering the aim of this research, our interest was focused on analyzing how students' perceptions changed when addressing ethical problems in design projects. To do this, we opted for a qualitative approach: an open questionnaire aimed at collecting perceptions, which was implemented as a pre-test (at the beginning of the experience) and a post-test (at the end of the experience) (Oliver-Hoyo \& Allen, 2006). We opted for open questions because they offer the possibility of collecting explanations of 
de pensamiento y de las experiencias de los individuos a la manera de visiones interpretativas (Merriam \& Tisdell, 2015). El cuestionario fue diseñado con cuatro preguntas fundamentales que nos permitieran obtener, de forma amplia, las visiones de los estudiantes: (a) ¿En qué momento del proceso de diseño sienten que pueden tener dilemas morales? (b) ¿Qué principios o conceptos creen que podrían incluir para ayudarse a resolverlos? (c) ¿Tienen alguna referencia ética para aplicar al proceso de diseño? (d) ¿Qué haría al enfrentar un dilema moral?

Con el fin de evaluar el alcance del set de tarjetas previamente desarrollado con los estudiantes más avanzados, decidimos comprobar su utilidad con estudiantes de primer y segundo año de la Carrera de Diseño de la Universidad de Los Andes (Figura 2). En el primer año, la aproximación al trabajo con personas y con instituciones reales genera incertidumbre y dudas en los estudiantes, lo que constituye el escenario ideal para la introducción del set, dado que este recoge las dudas identificadas previamente por estudiantes de cursos superiores de la misma carrera e intenta dar luz en la forma de indagar en ellas, de modo que los estudiantes puedan encontrar un camino de acción para enfrentar el dilema. En el segundo año se introduce el trabajo con comunidades y, dado que los estudiantes tienen ya una pequeña experiencia aproximándose a las personas, pudimos comparar la complejidad de las reflexiones. Aplicamos entonces el cuestionario con preguntas abiertas antes y después del uso del set de herramientas para estudiantes de primer año (31 estudiantes) y estudiantes de segundo año (26 estudiantes), lo que nos permitió analizar el nivel de conocimiento y aplicación de la ética en el proceso de diseño como un asunto que cambia a través del tiempo.

Los estudiantes que respondieron el cuestionario recibieron el tercer prototipo del set de tarjetas (Figura 3). Las reflexiones giran en torno a preguntas y los estudiantes tienen espacio para crear sus propias tarjetas. Además, el set contiene un cuadernillo guía donde los estudiantes encuentran referencias y explicaciones sobre los principios éticos y su relación con las etapas del proceso de diseño. the internal thought processes and the experiences of individuals in the manner of interpretive visions (Merriam \& Tisdell, 2015). The questionnaire was designed with four fundamental questions that allowed us to obtain, in a broad way, the views of students: (a) At what point in the design process do you feel you may have moral dilemmas? (b) What principles or concepts do you think you could include to help you solve them? (c) Do you have any ethical reference to apply to the design process? d) What would you do when faced with a moral dilemma?

In order to evaluate the scope of the set of cards previously developed with the more advanced students, we decided to test its usefulness with first- and second-year Design students at the University of Los Andes (Figure 2). In the first year, the approach to working with people and with real institutions feelings of uncertainty and doubts in the students, which constitutes the ideal scenario for the introduction of the set since it collects the doubts previously identified by students of higher courses of the same school and tries to shed light on how to investigate them so that students can find a course of action to deal with the dilemma. In the second year, working with communities is introduced and given that the students already have a little experience approaching people, we were able to compare the complexity of the reflections. We then applied the open questionnaire before and after the use of the toolkit for first-year students ( 31 students) and second-year students ( 26 students), which allowed us to analyze the level of knowledge and application of ethics in the design process as an issue that changes throughout time.

The students who answered the questionnaire received the third prototype of the set of cards (Figure 3). Reflections revolve around questions and students have space to create their own cards. In addition, the set contains a guide booklet where students find references and explanations about the ethical principles and their relation to the stages of the design process. 


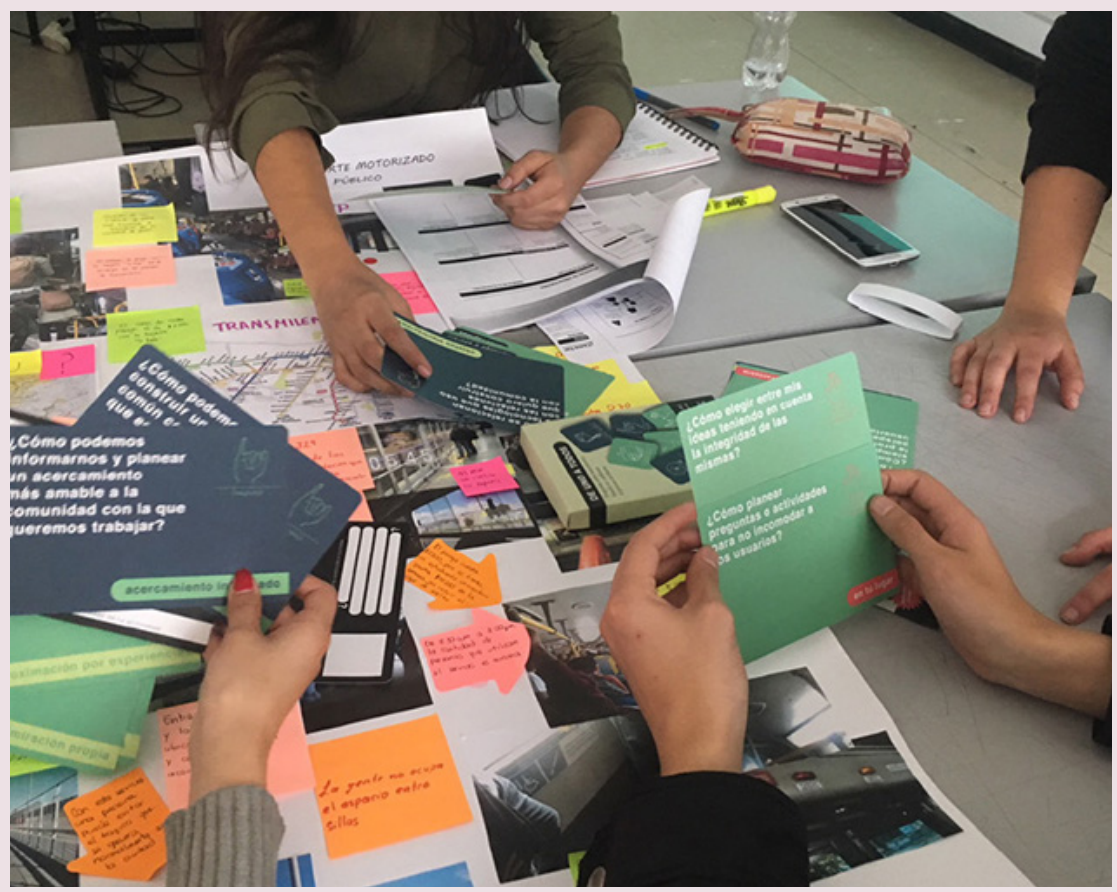

Figura 2: Socialización de las tarjetas con estudiantes de primery segundo año de la Carrera de Diseño de la Universidad de Los Andes.
Figure 2: Socialization of the cards with first- and second-year Design students of the Universidad de Los Andes.

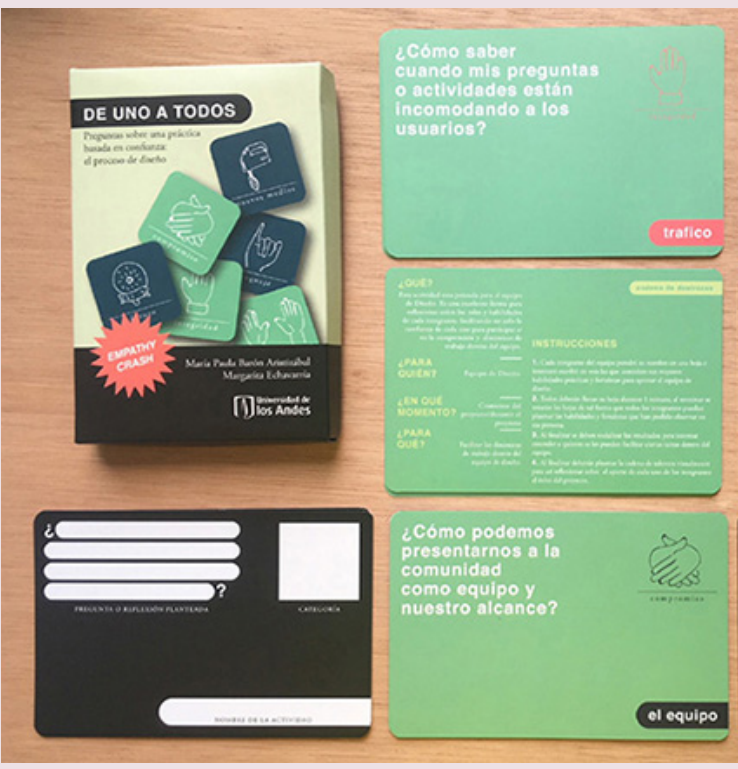

Figura 3: Set de tarjetas para el trabajo en clase y para validación con usuarios. Incluye tarjetas con preguntas y actividades, cuadernillo de explicación y tarjetas con espacio libre para la creación de nuevas actividades. Créditos: María Paula Barón Aristizábal, 2018.

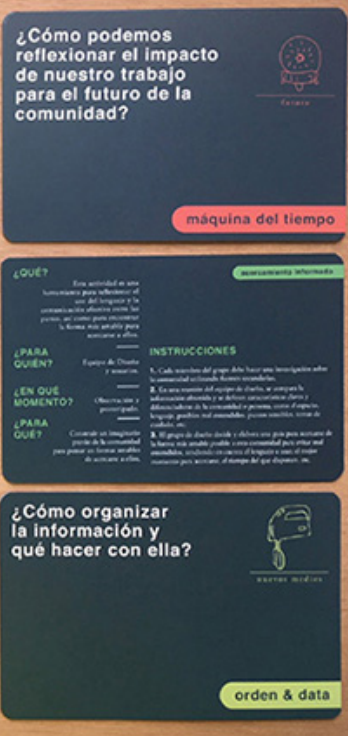

Figure 3: Set of cards for class work and for validation with users. Includes cards with questions and activities, an explanation booklet, and cards with free space for creating new activities. Credits: María Paula Barón Aristizábal, 2018. 


\section{Resultados}

Los estudiantes de primer año que respondieron el cuestionario antes de tener acceso al set de herramientas indican que sienten dilemas morales al acercarse por primera vez a las personas, al intentar construir confianza, al tocar temas complejos, al hacer el registro fotográfico y al pedir los permisos pertinentes. Asimismo, reconocen el trabajo en grupo y sus dinámicas como una instancia de gran dificultad. En general, los datos nos muestran que los estudiantes no tenían conocimientos robustos o referentes claros en el campo de la ética. Junto con ello, el cuestionario reveló que los principios o valores éticos que lograron relacionar con el proceso de diseño, antes de conocer el set de tarjetas, son el respeto y la honestidad.

Después de trabajar durante ocho semanas usando libremente el set de tarjetas en cursos en los que los estudiantes desarrollaron proyectos, encontramos cuatro categorías de análisis que recogen la utilidad que tiene para los estudiantes el set de tarjetas: (a) aproximarse con más tranquilidad a las personas al momento de aplicar cuestionarios y hacer entrevistas, (b) generar confianza en los procesos de diseño e implementación, (c) comprender el contexto y las relaciones que tienen los estudiantes con diferentes grupos de un determinado nivel socio-cultural, (d) validar la propuesta con los colaboradores y organizarse como grupo. El set se convirtió en una referencia ética que calificaron como "fácil de consultar".

Las respuestas de los estudiantes de segundo año al cuestionario pre-test no difieren mayormente de las que formularon los de primero, dado que identifican momentos similares como sensibles (acercamiento, confianza, registro y permisos). No obstante, pudimos dar cuenta de que los abordan con mayor profundidad. Los estudiantes se cuestionan asuntos relacionados con la instancia de recolección de información y las diferencias políticas o de clase que pueden tener con las comunidades, o simplemente los diferentes puntos de vista, y empiezan a cuestionar los alcances de su trabajo con la comunidad. Al igual que en el caso anterior, la mayoría de los estudiantes señala no contar con referentes teóricos o prácticos que los ayuden a resolver estos dilemas

\section{Findings}

First-year students - who answered the questionnaire before accessing the toolkit -indicate that they feel moral dilemmas when approaching people for the first time, when trying to create bonds of trust, when addressing complex topics, when carrying out the photographic record, and when asking for the relevant permits. Likewise, they recognize group work and its dynamics as an instance of great difficulty. In general, the data show us that the students did not have robust knowledge or clear references in the field of ethics. Along with this, the questionnaire revealed that respect and honesty were the ethical principles or moral values that they managed to relate to the design process, before knowing the set of cards.

After working for eight weeks, freely using the set of cards in courses in which the students developed projects, we found four categories of analysis that reflect the usefulness of the set of cards for students: (a) approach people more calmly at the time of applying questionnaires and conducting interviews, (b) build confidence in the design and implementation processes, (c) understand the context and the relationships that students have with different groups of a certain socio-cultural level, (d) validate the proposal with the collaborators and organize as a group. The set became an ethical reference that they described as 'easy to employ'.

The responses of the second-year students to the pre-test questionnaire, did not differ greatly from those of the first-year students, given that they identify similar moments as sensitive (approach, trust, data acquisition, and permissions). However, we discovered that they address them in greater depth. Students question issues related to the instance of collecting information and the political or social differences they may have with the communities, or simply the different points of view, therefore they begin to question the implication of their work with the community. As in the previous case, most of the students indicate that 
éticos. Los principios que consideran relevantes para la práctica del diseño son la honestidad y el respeto, al igual que estudiantes de primer año, incluyendo también la tolerancia, la discreción y la confidencialidad.

Una vez que los estudiantes de segundo año pudieron vivir la experiencia y usar el set de tarjetas, logramos consolidar tres grandes categorías que aglutinan sus pensamientos en torno a la utilidad del set: (a) apoyar procesos de co-creación, (b) procesar información, (c) establecer límites para proteger los datos y a las comunidades en el trabajo de campo. Los resultados indican que el set de tarjetas incide positivamente en que los estudiantes logren establecer principios más profundos de debate ético, así como referentes de importancia para poder llevar a cabo acciones y tomar decisiones que mejoran el desarrollo de un proyecto. Igualmente, pudimos notar un incremento de la empatía, ya que los estudiantes se empiezan a preocupar más por proteger moralmente a las personas vinculadas con sus proyectos. De este modo, podemos confirmar que el set de tarjetas produce cambios importantes en las concepciones de los estudiantes.

Comprobamos, además, que la mayor fortaleza de las tarjetas está en las preguntas éticas que surgen en las distintas etapas del proyecto de diseño y en la reflexión a la que invitan, incluso cuando la actividad no se lleva a cabo y es reemplazada por la discusión que genera la tarjeta. A partir de esto, creamos el set final para publicación y para uso en el salón de clase priorizando las reflexiones sobre las actividades (Figura 4). Incluimos 24 tarjetas divididas en los tres principios: compromiso, integridad y admiración, y en los tres medios explorados: lenguaje, futuro y nuevos medios. Cada tarjeta invita a un proceso de diseño más empático a partir de una pregunta y una reflexión que contiene actividades o consejos, y cada una de ellas define en qué etapa del proceso de diseño puede ser más relevante. Incluimos fichas vacías que invitan a los equipos de diseño a formular sus propias preguntas y estrategias. they do not have theoretical or practical references that help them solve these ethical dilemmas. The principles they consider relevant to the practice of design are honesty and respect, just like first-year students, also including tolerance, discretion, and confidentiality.

Once the second-year students were able to live the experience and use the set of cards, we were able to consolidate three large categories that bring together their thoughts about the usefulness of the set: (a) support co-creation processes, (b) process information, (c) set limits to protect data and communities at field work. The results indicate that the set of cards has a positive effect on enabling students to establish deeper principles of ethical debate, as well as important references of being able to take actions and make decisions that improve the development of a project. Likewise, we were able to notice an increase in empathy, as students begin to care more about morally protecting people linked to their projects. In this way, we can confirm that the set of cards produces major changes in the conceptions of the students.

We also confirm that the greatest strength of the cards lies on the ethical questions that arise in the different stages of the design project and in the reflection to which they invite, even when the activity is not carried out and is replaced by the discussion that each card ensues. From this, we created the final set for publication and for use in the classroom, prioritizing the reflections on the activities (Figure 4). We include 24 cards divided into the three principles: commitment, integrity, and admiration, and in the three explored media: language, future, and new media. Each card invites a more empathetic design process, based on a question and a reflection that contains activities or advice. Each of them defines at which stage of the design process it can be most relevant. We include empty cards that invite design teams to formulate their own questions and strategies. 

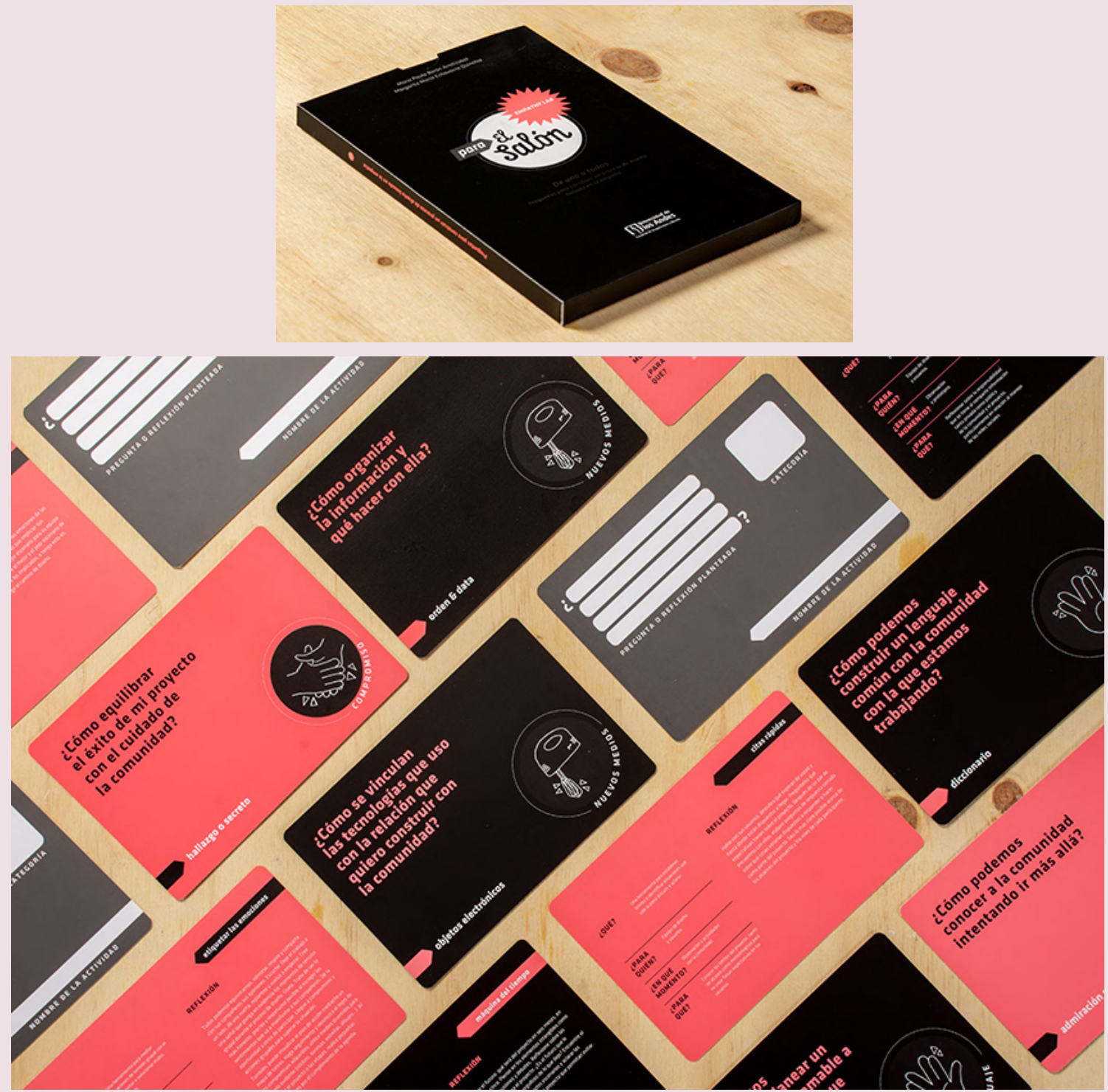

Figura 4: Resultado final del set de herramientas para uso en el salón de clase. Ver Barón Aristizabal \& Echavarría Quinchia, 2019.
Figure 4: Final result of the set of tools for use in the class-

room. See Barón Aristizabal \&

Echavarría Quinchia, 2019. 


\section{CONCLUSIONES}

Incluir reflexiones éticas y promover estas prácticas en el proceso de diseño detona en los estudiantes la motivación necesaria para pensar en proyectos más empáticos. Más allá de la creación de las dinámicas o el seguimiento paso a paso de actividades que responden a principios éticos, el valor de las tarjetas radica en que constituyen una herramienta atractiva y eficiente para que los estudiantes se cuestionen cuando aparecen dilemas morales y reflexiones sobre sus acciones futuras. La cualidad más valiosa del set es que gira en torno a preguntas con el fin de sembrar inquietudes. Igualmente, podemos notar un aumento de la empatía, ya que los estudiantes abordan en forma más compleja su intención de proteger moralmente a las personas vinculadas a sus proyectos.

A partir de esta experiencia reconocimos que el uso de las herramientas detona la creación de nuevas dudas o reflexiones. El set fomenta en los estudiantes la capacidad de indagar en dilemas morales. A su vez, la inclusión de fichas permite que estas dudas puedan materializarse y discutirse, volviendo este cuestionamiento en una práctica continua y dando espacio a la creación de reflexiones propias. Debido a las inquietudes y a la curiosidad que genera el set, y con el propósito de entregar referencias para quienes quieran ahondar en sus reflexiones, incluimos una guía con ejemplos concretos y prácticos que apoyan este proceso en los estudiantes.

Algunas de las reflexiones más poderosas que propone el set son las referidas a la autoevaluación y la autocrítica, así como al apoyo al trabajo con las personas. A esto apuntan los cuatro argumentos principales de utilidad que señalan los estudiantes: aproximarse con más tranquilidad a la interacción con personas durante la aplicación de cuestionarios o las entrevistas; generar confianza en los procesos de diseño e implementación; comprender el contexto y las relaciones que establecen todos los integrantes del equipo de diseño con las diferente comunidades con las que trabajan; validar la propuesta con los colaboradores y organizarse como grupo. El set se convirtió en una referencia ética que los estudiantes calificaron como fácil de con-

\section{CONCLUSIONS}

Including ethical reflections and promoting these practices in the design process, activates in students the necessary drive to think about more empathetic projects. Beyond the creation of dynamics or the step-by-step monitoring of activities that respond to ethical principles, the value of the cards lies in the fact that they constitute an attractive and efficient tool for students to question themselves when moral dilemmas appear and reflect on their future actions. The most valuable quality of the set is that it revolves around questions in order to sprout concerns. Likewise, we can notice an increase in empathy, as students address in a more complex way their intention to morally protect the people involved in their projects.

From this experience, we recognized that the use of the toolkit triggers the creation of new doubts or reflections. The set encourages students' ability to investigate moral dilemmas. In turn, the inclusion of forms enables these doubts to materialize and to be discussed, turning this questioning into a continuous practice, and giving space to the creation of one's own reflections. Due to the concerns and curiosity generated by the set, and with the purpose of providing references for those who want to deepen their reflections, we include a guide with concrete and practical examples that support this process in students.

Some of the most powerful reflections that the set propose are those referred to self-evaluation and self-criticism, as well as a guide to work with people. This is what the four main statements of the students regarding utility, point to-approaching the interaction with people more calmly when carrying out questionnaires or interviews; build confidence in the design and implementation processes; understand the context and the relationships that all members of the design team establish with the different communities; validate the proposal with the collaborators and organize as a group. The set became an ethical reference that the students described as easy to 
sultar, aminorando la incertidumbre propia de un proceso creativo y dando espacio a reconocer el valor de la conexión humana, la empatía y el reconocimiento del otro, todo lo cual queda en evidencia en las intenciones de establecer límites para proteger a las comunidades durante el trabajo de campo.

El set promueve una competencia clave en los profesionales del futuro: la autonomía para identificar, afrontar y apropiarse de una forma específica de aproximarse a las personas. Además, contribuye a establecer principios más profundos de debate ético, así como referentes para poder llevar a cabo acciones y tomar decisiones que aporten a un mejor desarrollo del proyecto. Más allá de ser una herramienta de reflexión ética, es importante resaltar que el set funciona como una herramienta para la educación del diseño, particularmente para estudiantes que cursan el primer año de su formación, ya que los ayuda a identificar cada etapa del proceso de diseño y a familiarizarse con las actividades relacionadas con estas, así como a entender la disciplina del diseño como un mecanismo de construcción de sociedad. Una manera simple, atractiva y constructiva para dirigir de manera empática la aproximación a la práctica del diseño. \ consult, reducing the uncertainty of a creative process and giving space to recognize the value of human connection, empathy, and recognition of the other, all of which is evident in the intentions to establish limits to protect the communities during the field work.

The set promotes a key competence for future professionals: the autonomy to identi$\mathrm{fy}$, confront, and appropriate a specific way to approach people. In addition, it contributes to establishing deeper principles of ethical debate, as well as references of being able to carry out actions and make decisions, which contribute to a better development of the project. Beyond being a tool for ethical reflection, it is important to highlight that the set works as a tool for design education, particularly for students who are in the first year of their training, as it helps them identify each stage of the design process and to become familiar with the activities related to these, as well as to understand the discipline of design as a mechanism for social making. A simple, attractive, and constructive way to empathically guide the approach to design practice. $\square$ 


\section{REFERENCIAS / REFERENCES}

BAMBERGER, M. (2012). Methodological Issues to Design and Implement Equity-focused Evaluations. In M. Segone (Ed.), Evaluation for Equitable Development Results (pp. 86-101). UNICEF.

BARÓN ARISTIZABAL, M. P., \& ECHAVARRÍA QUINCHIA, M. (2019). De uno a todos: Preguntas para construir un proceso de diseño basado en la empatía. Uniandes.

BURTON, B., HENRY, M., MCCOLGIN, D., \& SPINAT, D. (2013). Designing for Empathy: A Toolkit Created by Artefact. Artefact.

Desmet, P. M. A., \& PohlmeYer, A. E. (2013). Positive Design: An Introduction to Design for Subjective Well-Being. International Journal of Design, 7(3), 5-19.

FINDELI, A. (2001). Rethinking Design Education for the 21st Century: Theoretical, Methodological, and Ethical Discussion. Design Issues, 17(1), 5-17. https://doi. org/10.1162/07479360152103796

GREENE, J. C., BOYCE, A., \& AHN, J. (2011). A ValuesEngaged, Educative Approach for Evaluating Education Programs: A Guidebook for Practice. University of Illinois. https://comm.eval.org/ HigherLogic/System/DownloadDocumentFile. ashx?DocumentFileKey=75bc9c3b-b169-4529-b2d3$642056 \mathrm{~d} 95$ f 35 \& force Dialog $=0$

KELLEY, D., SURI, J. F., \& IDEO. (2016). The Little Book of Design Research Ethics. IDEO.

MEADows, D. H. (2008). Thinking in Systems: A Primer. Chelsea Green Publishing.

MERRIAM, S. B., \& TISDELL, E. J. (2015). Qualitative Research: A Guide to Design and Implementation. John Wiley \& Sons.

MONTEIRO, M. (2019). Ruined by Design: How Designers Destroyed the World, and What We Can Do to Fix It. Mule Books.

NUSSBAUM, M. C. (2005). El cultivo de la humanidad: Una defensa clásica de la reforma en la educación liberal. Paidós.

OLIVER-HOYO, M. T., \& ALLEN, D. (2006). The Use of Triangulation Methods in Qualitative Educational Research. 35(4), 42-47.

PAPANEK, v. (2012). Design for the Real World: Human Ecology and Social Change. Thames and Hudson.

SIMON, H. A. (2019). The Sciences of the Artificial. MIT Press.

WILDEVUUR, S. E., VAN DIJK, D., \& SCHOT, M. (2014). Enhancing the Value of Social Innovation: Introducing the 'People Value Canvas' to Support Designers in Value Creation. In J. Salamanca, P. M. A. Desmet, A. Burbano, G. D. S. Ludden, \& J. Maya (Eds.), The Colors of Care: Design \& Emotion 2014, 9th International Conference, Colombia (pp. 301-307). Uniandes. 